\title{
ANALYSIS OF COMPANY PERFORMANCE AND AUDIT OPINIONS IN INDONESIAN FOOD AND BEVERAGES COMPANIES
}

\author{
Febby Namira \\ PT. Bahana Sekuritas
}

\author{
Yosman Bustaman \\ Swiss German University, Tangerang, Indonesia
}

This paper analyzes relationship between company performance and audit opinion. We use some financial ratios as measurement of firm's performance such as liquidity, efficiency, profitability, market measurement and cash flows. This study uses food and beverages companies listed in Bursa Efek Indonesia (BEI) for five consecutive years from 2009 until 2013 as our sample data. Panel data analyses are used to regress our empirical model. After controlling with size of company and macroeconomics variables namely inflation rate and movement of Indonesian currency exchange rate against US dollar, we find that firm's liquidity, profitability, market ratios and company cash flow significantly affect the audit opinion. Large firm size does not influence the audit opinion significantly, meanwhile both macro economic variables inflation rate and exchange rate link negatively with audit opinion however do not significantly affect the opinion. Thin volume of transactions in foreign currency among these companies might lead to non-significant effect between audit opinion and exchange rate.

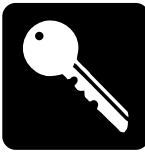

Company performance; liquidity; profitability; market measurement; cash flows performance; audit opinion. 


\section{INTRODUCTION}

$\mathrm{T}$ he competition among companies these days is getting tougher. Various ways are used in order to increase company's revenue and survive in this tough competition. One of the ways that is usually taken by the company is checking their financial statement, which is performed by a third party or auditor. The current and potential investors and creditors who do not deal directly with the auditor need an independent audited financial statement (Simunic \& Wu, 2009).

Financial statements contain the information about the company's performance (Yap, Yong, \& Poon, 2010). Using financial ratio cash flows ratio could assess firm's performance. Financial ratios are ways of linking and investigating the correlation between different parts of financial information (Arens, Elder, \& Beasley, 2012). Cash flows ratios are used to provide some important information about company's operation (Nahandi, Sarokolaei, \& Ghasemi, 2013).

The purpose of financial statements is to present a true and fair view of an entity's financial performance, financial position, equity and cash flows that is useful to a wide range of users in making economic decisions (Deloitte, 2009). Moreover, a financial statement is also might used as one of the management's responsibility to the owner. External parties also may need the company's information for decision making related to investment or merger.

Before the auditors come up with their opinion, they should perform necessary analytical procedure to get the opinion (Matarneh, 2011). Auditors perform analytical procedures to assess the client business risk and to understand the client's business. Kreutzfield and Wallace in Riyadi's (2011) prove that $40 \%$ of misstatements were detected from analytical procedure. There are five types of analytical procedures, which compare client's financial ratio with the industry data, compare client data with similar prior period data, compare client data with client-determined expected result, compare client data with auditor determined expected result and compare client data with expected result using nonfinancial data (Arens, Elder, \& Beasley, 2012).

The purpose of an audit report is often to communicate the information about audited financial statements between auditor and financial users. In the audit report, an auditor could express their opinion and describe the nature of the audit. Based on the standard of PCAOB, if the financial statement is not fairly stated, auditor may issue qualified opinion, adverse opinion, or disclaimer opinion (Public Company Accounting Oversight Board). Financial statements users do not read the whole audit's report. Moreover, non-professional investors do not even read the audit reports. External parties such as investors and bankers only focus on the result of audit opinion where there is an unqualified opinion (Mock, Turner, Gray, \& Coram, 2009).

The scandal of a big American company like Enron might be one of the largest corporate scandals in history. Enron might have manipulated their financial statement in order to attract the investors which involved Arthur Andersen as their auditor. This scandal had possibly give an affect to the big audit company. The auditors can carry out their responsibility against the employer and the society by audit quality control which is considered as the priority in the audit institution (Rudkhani 
\& Jabbari, 2013).

Al Matarneh (2011) found that auditors consider the activity ratio, profitability ratio, and long term paying ability ratio which could give effect to auditor's opinion. Whereas short term paying ability ratio and market (investment) ratio is not be considered by Jordanian auditor as ratios affect the auditor's opinion. Nahandi, Sarokolaei, and Ghasemi (2013), indicates that all cash flow ratios which are cash flows to assets, cash flows to sale, cash flows to stockholders' equity, operational earning to cash flows, net profit to cash flows are considered in predicting auditor's opinion except ratio of cash flows to stockholders equity. These authors view that cash flows can reduce the stakeholder's decision-making problem and provide the important information about financial operation. Rudkhani and Jabbari (2013) show that net earnings to gross earning ratio, return on asset, return on equity, net earnings to sale ratio, gross earnings to sale and investment return had significant impact to the audit opinion. Current ratio, invoice turnover ratio and quick ratio did not give an impact to the audit opinion.

There are still some speculations about the effect of financial ratio on audit opinion found in previous studies. Therefore, the primary purpose of this study is to analyze whether there is a relationship between financial ratio and audit opinion by using food and beverages company's financial statement listed in Bursa Efek Indonesia.

Currently, there are 16 food and beverages companies listed in Bursa Efek Indonesia. Investment in the food and beverage industry in 2014 is estimated at Rp.80 billion until 84 billion, growing by 10 $15 \%$ compared to this year's target of $\mathrm{Rp}$ 73 trillion. Sekretaris Jenderal Gabungan Pengusaha Makanan dan Minuman
Indonesia (Gapmmi) said that most of the investment made indicates that domestic demand is increasing and they also keep looking at opportunities to export its products. High investment growth will come from domestic investment and is believed to increase by $30 \%$ in 2014 (Suara Pembaruan, 2013). Because of that, this industry was chosen as data to be analysed in this research.

This research will use 5 classifications of financial ratio and 2 cash flows ratios in order to assess the company's performance, which are liquidity ratio, asset management ratio, debt management ratio, profitability ratio, market ratio, ratio of cash flow to total assets, and ratio of cash flow to sale by using a different study population. So, the author propose topic about "Analysis of the Financial Ratio in Relation to Audit Opinion in Food and Beverages Industry Listed in Bursa Efek Indonesia (BEI) for the Year 2009 to 2013."

\section{LITERATURE REVIEW II.I. Auditing}

Auditing is process of seeking the facts on each generated report especially a financial report by gathering the sufficient evidence (Loughran, CPA, 2010). Nowadays, demand for auditing is increasing which aims to allocate economic resources so that the quality of audit and reliability in a financial statement is more important (Saif, Sarikhani, \& Ebrahimi, 2012). For financial users such as investors, creditors, and owners, auditing could increase their reliability (Salehi, 2010).

An audit of a financial statement is a reasonable assurance engagement where the auditor gives an opinion about whether there is material misstatement and financial statement that has followed 
the accounting standards (CPA Australia, 2013). Certain companies needs an independent auditor to perform the audit of their financial statement because it becomes a foundation of trust in the world's financial system (Pricewaterhouse Coopers, 2013). Based on audited financial statements, financial user can make a financial decision (Kabajeh, Al Shanti, Dahmash, \& Hardan, 2012). When financial users wants to assess a company by using unaudited financial statement, they will asked for an auditor's report. Lack of an auditor's report could decrease the reliability of financial information (Mock, Turner, Gray, \& Coram, 2009). Therefore, an audited financial statement should be trustable, credible, and reliable.

\section{II.I.I Audit opinion}

An audit report is the main product of an audit by independent certified accountant, which is a tool to communicate between auditor and financial user (Salehi, 2010). The audit report that is issued by the auditor is important for many parties to make financial decision (Kabajeh, Al Shanti, Dahmash, \& Hardan, 2012). In an audit report, the audit opinion will be stated in different paragraph (PriceWaterhouseCoopers, 2013). Audit opinion is the auditor's responsibility to assess whether the financial statement is fairly stated in accordance with accounting standards and free from material misstatement, whether due to fraud and error.

An audit opinion could be influenced by some factors. Some researchers mentioned different factors that can affect audit opinion. Haron et al (2009) said that there are 3 factors that could affect the auditor judgments, which are financial indicators, disclosure, and evidence. Based on Naslmosavi, Sofian, and Maisarah's survey (2013) it was found that experience, education, skills, and employee competence are the factors that could influence on the quality of auditors and their opinion.

\section{II.II. Company's Performance And Predicted Audit Opinion}

It is generally known that financial statement could provide the information about firm's performance, stability, and future financial prospects (Yap, Yong, \& Poon, 2010). Financial ratio is a tool to assess the company's performance and position of an enterprise by understanding and interpreting the correlation between each element in the financial statements (Babalola \& Abiola, 2013). Florenz C. Tugas (2012) also mentions that financial ratio analysis is one of the tools of financial statement analysis. Cash flow ratio also might be used to for evaluating company's performance. Nahandi, Sarokolaei, and Ghasemi (2013) stated that cash flow ratio provides the important information about financial operation and non-profit unit status whose analysis could increase stakeholder's decision-making problems.

The auditor could perform audit test and further analysis by using financial analysis that might be used to predict the possible problems areas in the future. Unusual change could be disclosed by comparing ratios and prior research or industry data that can help an auditor to identify the possible misstatement that needs more attention during the audit (Arens, Elder, \& Beasley, 2012).

There are 5 classifications of financial ratio generally uses in the literature, they are liquidity ratio, asset management ratio, debt management ratio, profitability ratio, and market ratio. Liquidity ratio measures the ability of company to meet the unexpected need for cash to pay debt 
(Weygandt, Kimmel, \& Kieso, 2012). Liquidity ratio could assess the health of company as well. When the financial health of company is decreased, the likelihood of qualified audit report will be given by auditor is increased (Kirkos, Spathis, Nanopoulos, \& Manolopoulos, 2009). In the other words, the company that has low liquidity ratio may have a greater possibility to receive a qualified audit report. There are 3 important ratios in liquidity ratio, which are current ratio, quick ratio, and cash ratio.

Asset management ratio or efficiency ratio is used to measure how efficiently the company uses their existing asset to run the business (Brealey, Myers, \& Allen, 2011). This ratio may used to define the strengths of a company compared with their rivals. There are two important efficiency ratios, which are invoice turnover ratio and total assets turnover. Invoice turnover ratio is also called accounts receivables turnover. This ratio is useful for the auditor to evaluate the reasonableness of sales that have not been paid (Arens, Elder, \& Beasley, 2012). If customers pay the bills quickly and on time, the company may have only a less unpaid number of bills and the receivable turnover will be high. High receivables turnover also indicates that the company has good credit policy which means that company choose a trustworthy customer who are willing to pay the bills on time (Brealey, Myers, \& Allen, 2011). Another efficiency ratio is asset turn over ratio, which indicates how efficient the company uses the available assets in generating sales revenue (Brealey, Myers, \& Allen, 2011). However, Rudkhani \& Jabbari (2013) did not find significant relationship between this ratio andthe type of audit opinion.

Debt management ratio is also known as leverage ratio. Brealey, Myers, and
Allen (2011) stated that leverage ratio is to assess how the company use debt to generated income. Financial leverage usually uses debt ratio by measuring longterm debt to total long-term capital. If a company has very low debt ratio, it means that a company does not use leverage for owner's benefit, whereas if the debt ratio is too high, it means that company uses available leverage at maximum level so a company could not have additional debt (Arens, Elder, \& Beasley, 2012). Matarneh's (2011), Rudkhani and Jabbari, (2013) find that debt management ratio has the maximum effect to predict audit opinion.

The next measurement is profitability ratio reflects. Ross, Jordan, and Westerfield (2008), mentioned that profitability ratio is used to measure whether the company uses their asset efficiently and how manage its operation to generate their income and profit. This study uses return on equity (ROE) and earning before tax and interest to total revenue or operating profit margin. Profitability ratio is one of the ratios that has significant effect to predict auditor opinion (Al Matarneh, 2011). Rudkhani and Jabbari (2012) also stated that profitability ratio significantly affect auditor opinion.

Market ratios such as price to earnings ratio, dividend to earnings per share ratio, stock payment earnings ratio, and earnings ratio commonly uses to measure current price of stock in the market towards the ability of company to generate the income or assets. Rudkhani and Jabbari's (2012) shows that market ratio have significant effect in predicting the type of audit opinion. However, Matarneh (2011) find Jordanian auditors in predicting audit opinion do not consider that market ratio. Many analysts believe that payout ratio could assess the shareholders equity of the 
company. Parsian and Koloukhi (2014) mentioned that when dividend payout ratio of a firm is decreasing, a firm would get accumulated profit and also have investment opportunities to develop their business in the future. They also said that dividend payout ratio has an important role in the determining value of company's equity. Dividend to earnings per share ratio has significant effect in predicting type of audit opinion (Rudkhani \& Jabbari, 2013). These authors also prove that earnings per share ratio significantly effect audit opinion.

Operating cash flows also important in assessing Company's performance (Jooste, 2006). Cash flow ratio may useful in evaluating performance, which can be discussed in terms of sufficiency and efficiency. Efficiency indicates the fitness of obtained cash flows compared with another business units or previous years, whereas sufficiency indicates the ability of company in order to fulfil the operational needs (Nahandi, Sarokolaei, \& Ghasemi, 2013). There are 2 cash flow ratio used in this study, which are ratio of cash flows to total assets and ratio of cash flow to sale. Sarokolaei, and Ghasemi (2013) stated that cash flow to sale ratio one of ratio that can be used in predicting auditor opinion.

\section{II.III. Company Size And Audit Opinion}

Companies with positive growth might give a sign that the size of the company is growing and reduce the tendency towards bankruptcy. But, the size and complexity of company, might influence in achieving its control objectives. The company's size and its complexity also could affect the risk of the misstatement (Public Company Accounting Oversight Board, 2007). In the other words, the size of company might have higher risk of misstatement which is could influence to the audit opinion.

\section{II.4. Macroeconomics}

Macroeconomics explains about the behaviour of large economic agents, which is focus on the behaviour of consumers, firms, and government. It also explains the whole of economy activity in a country and effect of monetary and fiscal policy (Williamson, 2014). According to statement of auditing standard no. 55, when the auditor performs the audit, they have to understand the entity and its environment by looking at industry factors, regulatory factors, and external factors in order to identify and assess risk of material misstatement. The external factors that might be considered by auditors are inflation and currency revaluation.

Currency exchange rate is the price of nation's currency valued with another country's currency. The fluctuated exchange rate might have an affect on how economic transaction that use foreign currency poured into the financial statements. It is very important to avoid financial statement are not materially misstated or in other words, the financial statements still describe the actual economic reality (Sinaga, 2010).

Badan Pusat Statistik defines inflation as an indicator to see the economic stability of a region or area that shows the development of prices of goods and services in general are calculated from the consumer price index. Thus the inflation rate greatly affects the purchasing power of fixed-income communities, and on the other hand also influences the production of goods. Shortly, inflation could be defines as decline the purchasing power of money in general as a result of the 
increase in the level of prices of goods and services.

\section{METHODOLOHY III.I. Data}

The data uses in this research are financial report of food and beverages industry listed in Bursa Efek Indonesia (BEI) 2009 to 2013. There are 16 food and beverages companies that meet our criteria. The financial statement is gathered from the Indonesia Stock Exchange's website (www.idx.co.id) and Bloomberg which is used to measure the company's performance and company size. For macroeconomics variable, data are taken from Central Bank's website and BPSIndonesia statistics' website.

\subsection{Empirical Model}

The following regression model of panel data is used to measure the effect of company's performance towards audit opinion:

$$
\begin{aligned}
& Y_{i t}=\alpha+\beta_{1} \times L R_{i t}+\beta_{4} \times A M_{i t}+\beta_{6} \times D M_{i t}+\beta_{7} \times P P_{i t}+\beta_{10} \times M R_{i t}+\beta_{12} \times C F_{i t}+ \\
& \beta_{14} \times C Z_{i t}+\beta_{15} \times M A C_{i t}+\Sigma_{i t}
\end{aligned}
$$

$$
\begin{aligned}
& Y_{i t}=\alpha+\beta_{1} \times C R_{i t}+\beta_{2} \times Q R_{i t}+\beta_{3} \times C A R_{i t}+\beta_{4} \times A R T_{i t}+\beta_{5} \times A T_{i t}+\beta_{6} \times D E_{i t}+ \\
& \beta_{7} \times R O E_{i t}+\beta_{8} \times O P M_{i t}+\beta_{9} \times P E R_{i t}+\beta_{10} \times P A Y T_{i t}+\beta_{11} \times E P S_{i t}+\beta_{12} \times C F T S_{i t}+ \\
& \beta_{13} \times C F T A_{i t}+\beta_{14} \times T A_{i t}+\beta_{15} \times R_{i t}+\beta_{16} \times C E R_{i t}+\Sigma_{i t}(3.2)
\end{aligned}
$$

The equation above identifies explanatory variables that used in this study to estimate those variables towards audit opinion that in the regression audit opinion as dependent variable, financial ratio as independent variable, company's size and macroeconomics variables as control variables.

$\mathrm{Y}=$ Audit opinion
$\mathrm{LR}=$ Liquidity ratios, consists of current ratio measure by current asset over current liability, quick ratio is measured by liquid asset over current liability, and cash ratio is the ratio of cash plus marketable securities over current liability

$\mathrm{AM}=$ Asset management ratio, consists of invoice turnover (net sales/ account receivable) and asset turnover (net sales over total assets)

$\mathrm{DM}=$ Debt management ratio only consist of debt ratio (total debt over total equity)

$\mathrm{PR}=$ Profitability ratio are measured by return on equity $(\mathrm{ROE}=$ net income over total equity) and operating profit margin $(\mathrm{OPM}=$ operating income over total revenue)

MR $=$ Market ratio consists of price to earnings ratio $(\mathrm{PER}=$ Market Value per Share / Annual Earning per Share), dividend to earning per share ratio (PAYT $=$ Dividend $/$ Earnings per share), and earning per share ratio (EPS $=$ Net Income - Preferred Dividends / Weighted-average common stock outstanding)

$\mathrm{CF}=$ Cash flows are represented by operational cash flow over sales (CFTS) and operational cash flows over total asset (CFTA)

$\mathrm{CS}=$ Company's size is represented by total firm asset

$\mathrm{CER}=$ Current exchange rate

$\mathrm{IR}=$ Inflation rate

$\mathrm{ERR}=$ Error

Dependent variable of this study is type of audit opinion, which is divided into 2 variables (unqualified opinion and qualified opinion). The first variable is unqualified opinion and second aspect is qualified opinion, including the other opinions (adverse opinion and disclaimer 
opinion).

There are 2 control variables in this study, which are company size and macroeconomics. Macroeconomics consists of current exchange rate and inflation. As already mentioned that company's size is classified into 3 groups; big, medium, and small company that is measured based on the company's asset.

\section{RESULTS AND DIS- CUSSION \\ IV.1. Descriptive Statistic}

Table 1 shows the descriptive statistics of all variables in equation. The table consist of Mean, Median, Maximum, Minimum, Standard Deviation of variables.

Table 1 Descriptive Statistics of 10 Food and Beverages Companies

\begin{tabular}{|c|c|c|c|c|c|c|c|}
\hline & AUDIT & ART & AT & DER & ROE & OPM & PER \\
\hline Mean & 87654 & 9.411394 & 1.230866 & 1.067665 & 24.77852 & 13.16356 & 19.9159 \\
\hline Median & .000000 & 8.669300 & 1.192500 & 0.896661 & 18.43040 & 10.84550 & 15.0029 \\
\hline Maximum & 000000 & 39.77040 & 2.629800 & 14.01822 & 204.7779 & 48.36850 & 501.463 \\
\hline & 100000 & $\begin{array}{c}- \\
0.794106\end{array}$ & 0.040802 & 3.604380 & 169.8614 & 75.53110 & 66.6 \\
\hline \multirow[t]{2}{*}{ Std. De } & 0.110766 & 5.050339 & 0.485895 & 1.384268 & 44.83624 & 16.19212 & 45.1460 \\
\hline & s & $A Y$ & TS & CFTA & TA & $\pi v 1$ & ER \\
\hline Mean & 50.718 & 0.905404 & 0.102489 & 0.036709 & 1.277778 & 0.052312 & 9634.596 \\
\hline Median & 39.23920 & 0.000000 & 0.108770 & 0.036531 & 1.000000 & 0.046100 & 9470.548 \\
\hline & 85.00 & 9.051042 & 1.809525 & 0.239246 & 3.000000 & 0.084000 & 11683.75 \\
\hline Minimum & 12.05790 & 0.000000 & 1.352119 & $\begin{array}{r}- \\
0.235098 \\
\end{array}$ & 1.000000 & 0.027800 & 8590.367 \\
\hline & 0.452 & 1.674208 & 0.237792 & 0.063739 & 0.642685 & 0.017138 & 835.476 \\
\hline
\end{tabular}

As seen in the table, turnover of account receivable in food and beverages industry have an average of 9.41 with the highest value of 39.77 and the lowest value of -0.79. AR Turnover could indicate that the company have a strict credit policy (Gorczynska, 2011). Assets turnover ratio shows the total assets turnover measured by the volume of sales. The range value of assets turnover is from 2.63 to -0.04 and the mean is 1.23 , Debt to Equity Ratio describe extent to which the owner's capital to cover the debts. The average value of debt ratio is 1.06 which indicates that the companies' funds its operation with an even mix of debt and equity.

The mean of return on equity is $24.77 \%$ that is considered as strong. The average operating profit margin is $13.16 \%$ which is considered as vulnerable. It is indicates that this industry might have a lower price production or high expense or inefficient in the production. Price earnings ratio (PER) has an average of 19.91 within the range of -166.67 until 501.462. It can be said that Price Earnings Ratio in food and beverage industry is high. The high of price to earning indicates that the market price in this industry is expensive because company sell for 20 times of earnings.

Earning per Share (EPS) is a comparison of net profit after tax in the financial year and the number of shares issued. The mean for the variable of Earing per Share Ratio is Rp.1050.71 with the highest value is Rp.14.485 and the lowest value is Rp.-12.00. It can be said that earning per share in food and beverage industry is high, which means that most of companies in this industry successful in increasing the prosperity of shareholder and makes them happy because the greater profits is provided to shareholders.

The average of payout ratio is 0.90 within the range value from 0.00 to 9.05 , means that most of companies in this industry not pay dividends, and the company that pay dividend are paid $90 \%$ from their profit. The cash flow to sales ratio is range from -1.35 to 1.80 and the average value is 0.10 . It indicates that companies in this industry have good cash flow to sale ratio. Meanwhile mean of the cash flow to total asset variable is 0.03 . 


\section{IV.II. Analysis}

This study uses panel data regression which have 3 methods in panel data; Pooled Least Square, Fixed Effect Model, and Random Effect Model. Table 5 shows the result of regression panel data using 3 methods. Using the chow test and Hausmann test, model that is more appropriate for our data is Random effect.

Table 2 Regression Panel Data Estimation Results

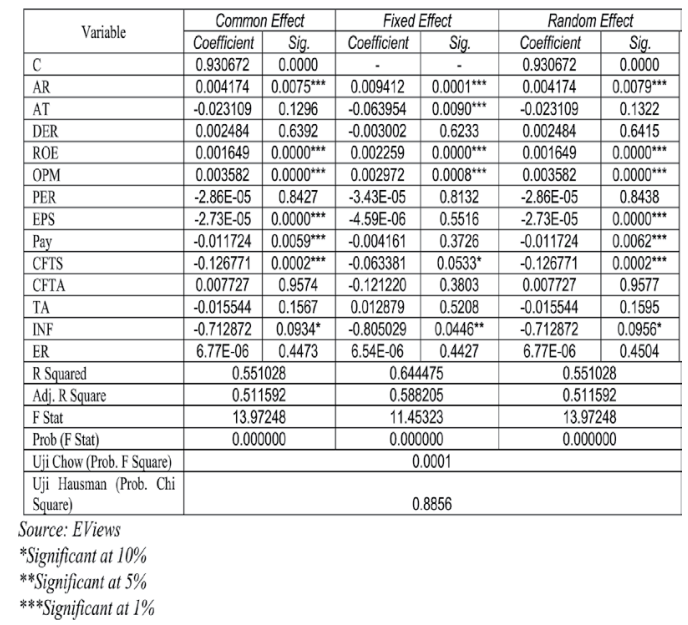

Account receivable turnover ratio has positively and significant affect with audit opinion. This ratio is useful to assess the effectiveness in extending credit and collect it back in a timely manner. This result indicates that if company has higher receivable turnover, it will reduce the likelihood of bankruptcy and increase the possibility to get good audit opinion. The findings are different with previous research that stated that has negative effect and no significant effect with audit opinion (Rudkhani \& Jabbari, 2013).

Debt to Total Equity has positive and no significant effect with audit opinion. Debt to Equity ratio is useful to show what proportion of stockholder's equity and debt used in order to financing the company's assets. High debt to equity means that most of company's capital comes from debt. As long as the interest rate is low, it generates benefits for company. Consequently, It reduces the likelihood of bankruptcy and increase the possibility to get good audit opinion. This result is consistent with finding obtained by Riyadi (2012) that debt to total equity has positive and no significant effect with audit opinion, but in opposite with Rudkhani and Jabbari, (2013) who find debt to equity has negatively significant effect with audit opinion.

ROE influences audit opinion positively. This ratio is useful to know how much the shareholders return from the money they invested (Kabajeh, AL Nu'aimat, \& Dahmash, 2012). Higher profit expects to reduce bankruptcy and increase the likelihood to receive good opinion. This result is consistent with previous study, where return on equity has positively significant effect with audit opinion, which means the higher return on equity of a company, the better opinion they will obtain (Maraputra, 2012).

Operating Profit Margin has positively significant effect with audit opinion. It means that the higher operating profit margin, the more possibility results in better audit opinion. This ratio usually uses to see how efficient the company is, because this ratio could show the level of expense of a company (Kantrovich, 2011). When a company has good operating profit margin ratio, it means the company's has low expense and high operating income. Thus, it would reduce the possibility of bankruptcy and increase the likelihood to get good audit opinion.

Price to earnings ratio has negative and no significant effect with audit opinion. This result can be interpreted that high or low price to earnings ratio does not have significant effect with audit opinion. Earnings per share ratio have negative and significant effect with audit opinion. 
EPS is useful to measure how much the shareholders will get from each share (Weygandt, Kimmel, \& Kieso, 2012). The result of this study is consistent with finding obtained by Rudkhani and Jabbari, (2013). Payout Ratio has negative and has significant affect with audit opinion. Our finding this study is consistent with the previous one, which mentioned that payout ratio has negatively significant effect with audit opinion (Rudkhani \& Jabbari, 2013).

Cash flow to sale (CFTS) ratio has negatively significant effect with audit opinion. The more cash generated from the sales indicates the improvement of the management decisions regarding variable cost that relates to the operational of the company (Amuzu, 2010). In the other words, this ratio describe how well the management performance in order to generate cash from net operations. This result is different with Nahandi et al (2013) who report that cash flow to sales has positively significant effect with audit opinion

Total asset is a control variable in this study, this variable associate negatively with audit opinion however is not significant. Inflation has negative and no significant effect with audit opinion. High inflation might encourage people to manipulate their financial statement or window dressing to attract the investors. Therefore, it would increase the likelihood to get bad opinion from auditor.

The fluctuations of exchange rate might influence the economic transaction, especially for company that used foreign currency that is poured into financial statement. For this kind of company, they should ensure that their financial statement describes the actual economic condition and free from the material misstatement (Sinaga, 2010). Exchange rate has negative and does not have significant effect with audit opinion. Thin transactions in foreign currency among these companies might lead to non significant effect between audit opinion and exchange rate.

\section{CONCLUSIONS}

This study analyse financial ratio in relation to audit opinion in food and beverages industry listed in Bursa Efek Indonesia (BEI) for the year 2009 to 2013. The sample of this study is 10 companies listed in Bursa Efek Indonesia and uses panel data analysis.

Asset management ratio is consists of account receivable turnover and assets turnover. Account receivable turnover has positively significant effect with audit opinion. The result of this study is different with previous research that stated that this ratio has negative effect and no significant effect with audit opinion. Whereas the result of assets turnover is negative and no significant effect with audit opinion, so it's the consistent with Rudkhani and Jabbari (2013) but different from Riyadi (2012), where assets turnover has positive significantly affect audit opinion.

Debt management ratio is represented by debt ratio, has positive and no significant effect with audit opinion. This result is consistent with Riyadi (2012), but different with previous research that is debt to total equity has negatively significant effect with audit opinion (Rudkhani \& Jabbari, 2013).

Profitability ratio consists of return on equity and operating profit margin. Return on equity has positive and significant effect with audit opinion. This result is different with Rudkhani and Jabbari (2013) who note negative and significant effect with audit opinion. Operating profit margin has positive and significant affect 
to audit opinion, which different with the previous finding obtained by Rudkhani and Jabbari, (2013).

Market ratio is represented by price to earnings ratio, earnings per share, and payout ratio. Price to earnings ratio (PER) has negative and not significantly affect audit opinion. It is contrast with the previous study that mentioned the Price to Earnings has significant effect with audit opinion. Earning per share has negative and significant effect with audit opinion. The result of this study consistent with finding of Rudkhani and Jabbari, (2013). For payout ratio, the result is negatively significant affect audit opinion, which is consistent with previous research.

Cash flows ratio has significant effect with audit opinion. Cash flow ratio is consist of cash flows to assets and cash flows to sale. Cash flow to sale ratio has negative significantly affect audit opinion. The result of this study different with previous research (Nahandi et al 2013), which mentioned that cash flow to sale have significant effect with audit opinion. Whereas cash flow to total asset has positively and does not significant affect audit opinion.

\section{REFERENCES}

Al Matarneh, G. F. (2011). Effect of using Financial Ratios on the Auditor's Opinion : Evidence from Jordan.

Amuzu, M. S. (2010, March). Cash Flow Ratio as Measure of Performance of Listed Companies in Emerging Economies: The Ghana Example.

Arens, A. A., Elder, R. J., \& Beasley, M. S. (2012). Auditing and Assurance Services (Fourteenth Edition ed.). Pearson.
Babalola, Y., \& Abiola, F. (2013). Financial Ratio Analysis of Firms : A tool for Decision Making, 1.

Brealey, R. A., Myers, S. C., \& Allen, F. (2011). Principles of Corporate Finance (Tenth Edition ed.). Mc-Graw Hill.

CPA Australia. (2013, February). A Guide to Understanding Auditing and Assurance.

Deloitte. (2009). IAS 1 - Presentation of Financial Statement.

Gorczynska, M. (2011, September). Account Receivable Turnover Ratio. The Purpose of Analysis in Terms of Credit Policy Management.

Haron, H., Hartadi, B., Ansari, M., \& Ismail, I. (2009). Factors Influencing Aduitor Going Concern Opinion. vol. 14.

Jooste, L. (2006). Cash flow ratios as yardstick for evaluating financial performance in African business.

Kabajeh, D. M., AL Nu'aimat, D. A., \& Dahmash, D. N. (2012). The Relationship between the ROA, ROE and ROI Ratios woth Jordanian Insurance Pblic Companies Market Share Prices. 2, 115120.

Kabajeh, D. M., Al Shanti, D. M., Dahmash, D. N., \& Hardan, D. S. (2012). Informational Content of Auditor's Report and its Impact on Making Decision From Lenders and Management's View in the Jordanian Industrial Public Firms. 2.

Kantrovich, A. (2011). Financial Ratios: Operating Profit Margin.

Kirkos, E., Spathis, C., Nanopoulos, A., \& Manolopoulos, Y. (n.d.). Predicting Qualiffied Auditor's Opinion : A Data Mining Approach.

Loughran, CPA, M. (2010). Auditing for Dummies. WIley Publishing, Inc. 
Matarneh, G. F. (2011). Effect of using Financial Ratios on the Auditor's Opinion: Evidence from Jordan.

Mock, T. J., Turner, J. L., Gray, G. L., \& Coram, P. J. (2009, April). Unqualified Auditor's Report: A Study of User Perceptions, Effects on User Decision and Decision Processes, and Directions for Future Research.

Nahandi, Y. B., Sarokolaei, M. A., \& Ghasemi, S. (2013). Evaluating the Ability of Cash Flow Ratio in Predicting Auditor's Opinion.

Naslmosavi, S., Sofian, S., \& M. B. (2013). The effect of Audit Firm Size on Independent Auditor's Opinion: Conceptual Framework. 9.

Parsian, H., \& Koloukhi, A. S. (2014). A study on the effect of free cash flow and profitability current ratio on dividend payout ratio: Evidence from Tehran Stock Exchange.

PricewaterhouseCoopers.

Understanding a Financial Statement Audit.

Public Company Accounting Oversight Board. (2007). PCAOB Auditing standard no. 5.

Public Company Accounting Oversight Board. (2013). Retrieved from www. pcaobus.org

Riyadi, T. (2011). Analisis Pengaruh Rasio Profitabilitas, Likuiditas, dan Solvabilitas Terhadap Opini Audit.

Ross, S. A., Westerfield, R. W., \&
Jordan, B. D. (2008). Corporate Finance Fundamental. McGraw-Hill .

Rudkhani, T. G., \& Jabbari, H. (2013). The Effect of Financial Ratios on Auditor Opinion in The Companies Listed on TSE.

Saif, S. M., Sarikhani, M., \& Ebrahimi, F. (2012). Finding Rules for Audit Opinions Prediction through Data Mining Methods. 1.

Salehi, M. (2010). Evaluating Effectiveness of External Auditors' Report: Emprical Evidence from Iran.

Simunic, D. A., \& Wu, X. (2009). ChinaRelated Research in Auditing: A Review and Directions for Future Research.

Sinaga, T. (2010). Pengaruh Ketidakstabilan Nilai Tukar Rupiah Terhadap Kualitas Laporan Keungan dan Keputusan Ekonomi.

The Power of Cash Flows. (2009).

Tugas, F. C. (2012). A Comparative Analysis of the Financial Ratio of Listed Firms Belonging to the Education Subsector in the Philippines for the ears 2009-2011. vol. 3 .

Weygandt, J. J., Kimmel, P. D., \& Kieso, D. E. (2012). Managerial Accounting (6th Edition ed.). John Wiley \& Sons, Inc.

Williamson, S.D.(2014). Macroeconomics (fifth edition ed.). Pearson.

Yap, B. C.-F., Yong, D. G.-F., \& Poon, W.-C. (2010). How well do financial ratios and multiple discriminants analysis predict company failures in Malaysia. 